\title{
КОНСТИТУЦИОННАЯ РЕФОРМА В КАНАДЕ: ПОЛИТИКО-ПРАВОВЫЕ АСПЕКТЫ
}

Аннотация: Работа посвящена формам и средствам преодоления правовых и политических препятствий на пути обновления высшего закона государства. В качестве иллюстрации избран конституционный процесс одного из старейших и наиболее уважаемых конституционных демократических государств, принадлежащего к правовой семье стран «общего права». Вскрываются основополагающие и специфические черть сложивщегося в этом североамериканском государстве механизма конституционно-правового регулирования. В том числе рассматривается роль и место таких источников правового регулирования, как конституционно-правовой обычай и прецедент, в конституционной доктрине и практике изучаемой страны. Определяется степень необходимости и цуелесообразности конституционной реформы, прослежены ее основные этапь. Анализируется воздействие, оказанное ее проведением на современное состояние канадского конституционализма. Оиенивается уровень управленческого искусства институтов федеральной власти в реализации реформьл. Работа построена на применении системно-комплексной методологии, включающей аналитический, формально-логический, сравнительный и исторический методы исследования. В статье впервыле в отечественной научной литературе подробно рассматриваются как правовые, так и социально-политические аспекты обновления писаной части неконсолидированной Конституции зрелого демократического государства. Упор сделан на выявлении трудностей в проведении реформы и на взаимовлиянии права и политики в рамках верховенства права. Дается оценка управленческого искусства, проявленного федеральной исполнительной властью в преодолении стоявщих перед ней препятствий при реализации реформы.

ключевые слова: Право, патриация, толкование, федерация, поправки, политика, консенсус, прецедент, коныенциии, конституциия.

Abstract: This works is dedicated to the ways and means of overcoming the legal and political hurdles on the path to reform the supreme law of the nation. As an illustration, the author chooses the constitutional process of one of the oldest and most respected constitutional democratic countries belonging to the legal family of nations of "common law". The article reveals the fundamental and specific features of the mechanism of legal constitutional regulation that has formed in this North American country, including the role and place of such sources of legal regulation as legal constitutional tradition and precedent within the constitutional doctrine and practice of this nation. The author defines the level of the necessity and reasonableness of a constitutional reform and follows its main stages; analyzes the effect of the reform upon the modern state of Canada's constitutionalism; evaluates the level of administrative skills of the institutions of federal authority in realization of the reform.

Keywords: Law, Patriation, Interpretation, Federation, Amendments, Policy, Consensus, Precedent, Conventions, Constitution.

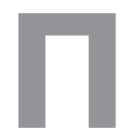

оложения любой конституции со временем неминуемо перестают отвечать меняющимся потребностям развития общества и/или государства. Решением проблемы является пересмотр конституции - частичный или всеобъемлющий, который вкупе с его политическим сопровождением получил на рубеже XX и XXI вв. емкое наименование конституционной реформы (ранее у теоретиков и практиков было принято говорить о «принятии и изменении конституции») ${ }^{1}$

Конституционные реформы - удел большинства стран независимо от их места на правовой карте мира. В государствах «молодой демократии» обычным

\footnotetext{
${ }^{1}$ Подробнее см., например: Windlewsham L., Hennessey D.G. The Politics of Constitutional Reform// Public Law. 2006. № 1. P.35 - 57.
} 
явлением стало проведение таких реформ в среднем каждые одно-два десятилетия. Скоропалительные модернизации конституционного механизма принято объяснять и оправдывать необходимостью адекватного реагирования права и государства на ускорение темпов социального прогресса. Подобные аргументы, неотличимые от правового нигилизма, не выдерживают критики при обращении к опыту конституционных реформ в государствах зрелого конституционализма и устоявшейся демократии ${ }^{2}$, которым присущи не меньшие темпы экономического и политического развития. Среди таких стран видное место принадлежит Канаде.

Конституция Канады - Акт о Британской Северной Америке (АБСА - 1867г.) характеризуется зарубежными учеными в качестве «немыслимого и небывалого ранее правового и политического эксперимента»³. Данное определение обосновано. Акт закрепил создание в рамках Британской империи федеративного доминиона, переставшего быть колонией, но не обладавшего суверенитетом. Была создана модель договорной федерации с монархической формой правления.

Доминион наделялся правом на собственное законодательство и институты власти, включая финансовую систему. Принятие писаной Конституции шло вразрез с доктриной и практикой метрополии и отражало влияние конституционного опыта США и Франции. Вместе с тем в преамбуле Акта закреплено: «Конституция Канады сходна в принципе с Конституцией Соединенного Королевства» ${ }^{4}$.

АБСА образовал писаную часть неконсолидированной Конституции, поскольку конституционные конвенции Соединенного Королевства, его правовые прецеденты и статутное право автоматически стали частью правовой системы Канады. Высшей судебно-апелляционной инстанцией страны остался Юридический комитет Тайного совета, выполнявший вплоть до 2009г. функции высшего имперского суда. Канадцы остались подданными британской короны, а флаг и гимн доминиона - британскими. Изменение статей Акта, внешняя и военная политика были оставлены в сфере юрисдикции парламента метрополии, что не давало доминиону права вступать в международные договоры и соглашения, состоять в международных организациях.

${ }^{2}$ См.: Богдановская И.Ю. Классификация конституций стран «общего права» // Право. Журнал Высшей школы экономики. 2012. №1.

${ }^{3}$ Jovell J. et al. The Changing Constitution. Oxford, 2000. P. 211.

${ }^{4}$ Конституция Канады приводится по: Canada. A Consolidation of Constitutional Acts 1867 - 1982. Ottawa, 2001.
Уникальный статус Канады как несуверенного федеративного государства был усвоен правовой доктриной с большими трудностями. Так, германский конституционалист Г. Еллинек писал: «Обладающие широкой автономией Канада, Австралия, Капская земля - не суть государства». Правда, в другом месте той же работы Еллинек, в противоположность не менее маститым конституционалистам Л. Дюги и В. Орландо, счел возможным причислить Канаду к государствам ${ }^{5}$.

Статьи АБСА не уточняли этнического состава населения доминиона. Напряженность в отношениях англоязычного большинства и франкоязычного меньшинства была растворена творцами Акта в частном вопросе об использовании французского языка в федеральном парламенте. АБСА закрепил территориальный тип федерации.

Самые известные нормы Акта содержат ст. 91-я и 92-я, разграничивающие сферы ответственности двух уровней власти. Сепаратизм и гражданские войны во многих федерациях ${ }^{6}$ привели авторов Акта к выводу о целесообразности двух исключительных и жестко разграниченных сфер компетенции - федеральной и провинциальной.

К безраздельной компетенции федерального центра Канады в АБСА отнесено 14 предметов, среди которых - регулирование банковского дела, торговли и обмена между провинциями, уголовное законодательство, право вето над провинциальным законодательством, мореплавание, рыболовство, сельское хозяйство, органы безопасности. Некоторые отечественные авторы утверждают, что указанные предметы отнесены основателями доминиона к «важнейшим вопросам жизни страны ${ }^{7}$. Подобное прочтение первоисточника ошибочно: в оригинале Акта, как и в русском его переводе, такого или аналогичного критерия распределения предметов компетенции нет.

В сфере исключительной компетенции провинций находится 16 предметов, в том числе гражданское законодательство, охрана гражданских прав, отправление правосудия, просвещение, здравоохранение, социальное вспомоществование, корпорации, муниципальное самоуправление. Ст.109-я подтверждает

\footnotetext{
${ }^{5}$ Г. Еллинек. Общее учение о государстве. СПБ. 2005. С.473, $626-627$.

${ }^{6}$ В Швейцарии в 1847 г., в США в $1861-1865$ гг. В латиноамериканских федерациях - Бразилии, Венесуэле. Мексике - гражданские войны не прекращались на протяжении практически всего XIX в.

${ }^{7}$ И.М. Денека. Канадский федерализм: взаимоотношения центра и провинций. М., 2004. С.28 - 29.
} 


\section{Право и политика $5(185) \cdot 2015$}

право провинциальной собственности на «землю и полезные ископаемые на территории провинций» ${ }^{8}$. Ст. 92(16) Конституции закрепляет за провинциями регулирование всех других вопросов «местного или частного характера». Перечень предметов провинциальной компетенции таким образом, оставлен открытым, тогда как набор предметов федеральной компетенции сделан закрытым.

В разграничении сфер ответственности двух уровней власти творцы Акта не были последовательными. Показательны нормы ст.95-й:«Всякий закон о земле или иммиграции в провинцию, изданный провинциальной ассамблеей, имеет силу до тех пор и постольку, пока и поскольку он не противоречит какому-либо акту парламента Канады». На первый взгляд статья утверждает перевес федерального права над правом субъектов и отвечает только интересам центра. Фактически же она устанавливает совместную (совпадающую, конкурирующую) компетенцию над сельским хозяйством и миграциями народонаселения. Но внедрение совместной компетенции, пусть и латентное, неизбежно противоречит принципу жесткого разграничения исключительных сфер компетенции.

Не вносит ясности в разграничение компетенции ст.94-я, которая разрешает центру «принимать законы о единообразии провинциальных законов о собственности и о гражданских правах». Правда, в статье указано, что подобный статут обретает силу после его утверждения провинциальной ассамблеей, что опять-таки вразрез с буквой АБСА - может быть истолковано как закрепление совместной сферы компетенции.

В отечественной литературе утверждается, что АБСА наделил провинции равным статусом, являющимся отличительным признаком симметричной федерации 9 . При этом исследователи упускают из виду нормы ст. 94-й и 97-й Акта, регулирующие законодательство о гражданских правах и о судопроизводстве провинций, кроме Квебека. Эти статьи узаконили в латентной форме правовую привилегию Квебека и придали федерации черты асимметричности. С принципом равноправия субъектов расходятся также нормы ст. 69й, 71-80-й и 88-й АБСА. Вводя единый срок полномочий всех провинциальных ассамблей, они одновременно закрепляют их дифференцированную организацию. Структуре и составу однопалатных ассамблей Новой

\footnotetext{
8 Доминион тогда не считался богатым природными ресурсами.

${ }^{9}$ См.: Качанов B.A. Федерализм в Канаде / Современный буржуазный федерализм. М.: Наука, 1978. С.88; Чиркин В.Е. Современный федерализм: сравнительный анализ. М.: ИНИОН РАН, 1997. C.28 -29.
}

Шотландии и Нью-Брансуика Акт посвящает одну статью, однопалатной легислатуре Онтарио две, а двухпалатной легислатуре Квебека - 10 статей. Добавим, что власти Квебека оградили также свое право на рецепцию Кодекса Наполеона. Данная уступка явилась компенсацией Квебеку за построение федерации по территориально-географическому признаку. Квебек с тех пор является страной «смешанного права», подобно Шотландии в Великобритании и Луизиане в США, тогда как все прочие провинции и сама федерация принадлежат к семье «общего права». В свете сказанного напрашивается вывод, что Квебек изначально обладает «специальным статусом».

Вместо интеграционной и симметричной федерации Акт закрепил компромиссную модель, включавшую элементы асимметричного и деволюционного федеративного государства. Подобное было сделано впервые в конституционной практике Нового времени.

В статьях 3-й, 138-й,146-й и 147-й статьях Акта основатели доминиона по настоянию Квебека и Новой Шотландии назвали страну «конфедерацией». Юридически неадекватный термин ${ }^{10}$ использовался затем свыше ста лет. Отступление от юридического подхода в угоду политической конъюнктуре породило двусмысленность в понимании характера административно-территориальной организации доминиона.

Среднесрочные и долгосрочные последствия применения Конституции, неконсолидированный характер которой не препятствует появлению новых правовых прецедентов и конституционных конвенций, предстают в следующем виде:

1. Ввиду не предвиденного никем в 1867г. опережающего развития природно-ресурсной экономики страны провинциальный уровень власти получил в XX в. важный и независимый от центра источник доходов, что значительно упрочило позиции субъектов федерации в их отношениях с Оттавой.

2. В странах «общего права» преобладающая часть всех возникающих в обществе и государстве

\footnotetext{
${ }^{10}$ Юристы - конституционалисты и политологи подвергают обоснованной критике «темный» язык АБСА, отягощенный терминологической путаницей и другими редакционными недоработками. В англоязычном оригинале АБСА нет терминов «конфедерация» или «федерация». Использован термин «союз» (union), который тогда понимали расширительно и которым могли называть любую из государственных форм . Исключительно для обозначения конфедерации термин стал применяться только в ХХ в. В современных официальных публикациях резонно отмечается: «Отцы-основатели нашей страны использовали термин «конфедерация» чрезмерно вольно» (Government of Canada. Notes on Canadian Federalism. Ottawa, 1992. P.5).
} 
коллизий регулируется органами судебной власти ${ }^{11}$. Многочисленные судебные разбирательства об уточнении разграничения предметов компетенции в большинстве случаев завершались решениями в пользу провинций. Толкуя пробелы и нестыковки в писаной части неконсолидированной Конституции, суды доминиона и метрополии исходили из непреложного факта -АБСА не создал провинций и потому не может являться источником их компетенции. Права провинций первичны, и их следует толковать расширительно. Права доминиона не могут быть истолкованы аналогично, ибо они вторичны. «Центру разъяснили, что фактически его власть производна от власти провинций» ${ }^{12},-$ комментируют канадские специалисты.

3. Прямым следствием прецедентов судебного толкования стало, во-первых, юридически полноценное расширение конституционно закрепленной сферы провинциальной компетенции и, во-вторых, фактическое возникновение совместной (конституционно не закрепленной) сферы компетенции. В доктрине и судебной практике появилось проистекающее из совокупности судебных прецедентов положение, гласящее, что «подразумеваемые (т.е. не перечисленные в АБСА и в парламентских статутах) полномочия принадлежат провинциям». К середине XX в. относится возникновение конвенции, по которой появление каждого нового предмета правового регулирования влечет за собой дальнейшее расширение сферы компетенции субъектов федерации. Оттава вправе препятствовать этому в рамках переговорного процесса, однако в ее распоряжении нет правовых средств, позволяющих вести переговоры с позиции силы.

4. Данные процессы сделали правомерной выработку провинциями новых форм и средств межрегионального сотрудничества, не предусмотренных, но и не запрещенных нормами АБСА и статутного права. Провинциальные правительства перешли к регулярным (в среднем раз в два-три года) конференциям ${ }^{13}$, которые созывались и работали помимо институтов федеральной власти. Когда центр счел целесообразным участвовать в конференциях, возникла еще одна конституционная конвенция: Оттава на них не обладает

\footnotetext{
${ }^{11}$ Подробнее см.: Богдановская И.Ю. Эволюция судебного прецедента в «общем праве» // Право. Журнал Высшей школы экономики. 2010. №2. С.75 - 87 .

${ }^{12}$ The Crosscurrents. Centralization versus Separatism / ed. by Charlton M., Barker P. Scarborough (Ont.), 1994. P.112.

${ }^{13}$ Первоначальное наименование этого института - колониальные конференции, позднейшие - федерально-провинциальные (ФПК), конституционные конференции.
}

правом решающего голоса. Присоединение центра к конференциям придало им законченный правовой статус, но обернулось дополнительным успехом провинциального уровня власти в его отношениях с Оттавой.

5. Провинции, пользуясь судебными толкованиями и принципом общего права «Разрешено все не запрещенное», проявляют большую активность в нормотворчестве. Гражданское и административное право Канады развивается в основном в рамках права провинций. Реализуя полномочия в регулировании «местных дел», одни провинции приняли фактически равноценные конституционным поправкам Билли о правах, другие - несколько более ограниченные по сфере применения Кодексы прав человека. С их принятием расхождения в правовом статусе личности в различных регионах федерации не могли не возрасти. Часть провинций, практикует не предусмотренные Конституцией народные волеизъявления по образцу штатов США и кантонов Швейцарии. В частности, получили известность проведенные в разное время Квебеком и Ньюфаундлендом референдумы об их статусе и отношениях с остальной Канадой.

Притязания составных частей страны на статус субъектов международного права проявились в Канаде раньше и в более отчетливых формах, чем в любой другой современной федерации. Провинции без согласования с центром открывают за рубежом агентства и офисы. Правительства нескольких провинций добились возведения этих учреждений в ранг генеральных консульств ${ }^{14}$. Субъекты вступают в соглашения с иностранными державами и их субъектами. Атлантические провинции заключили серию природоохранных соглашений с пограничными американскими штатами. Альберта, усматривающая в вывозе энергоносителей за пределы провинции «вопрос местного значения», связана соглашениями с провинциями КНР и префектурами Японии о продаже топлива. Квебек, считая «местным вопросом» развитие культуры и техники, без консультаций с Оттавой заключил с Францией Соглашение о сотрудничестве в данных сферах. Чтобы ввести прецедент в рамки общегосударственной политики, центр был вынужден в срочном порядке подписать не нужный ему Договор о сотрудничестве с Францией.

Серьезные прецеденты в сфере международного права созданы Британской Колумбией и Онтарио. Их правительства нашли, что федеральная власть вторглась в сферу провинциальной компетенции, заключив

\footnotetext{
${ }^{14}$ По состоянию на 2014 г. канадские провинции содержат в зарубежных странах порядка 200 учреждений - в среднем около 20 на каждую провинцию.
} 
DOI: $10.7256 / 1811-9018.2015 .5 .13829$

При цитировании этой статьи сноска на dоі обязательна

\section{Право и политика 5 (185) 2015}

со США Договор о водных ресурсах и Соглашение о расчистке Великих озер. Провинции, угрожая судебными исками, добились статуса полноправных сторон упомянутых международно-правовых актов. Оттава и Вашингтон согласились возложить ответственность канадской стороны за выполнение Договора о водных ресурсах на Британскую Колумбию, хотя она не является государством. А Онтарио заявило правительству США протест после проведения им подземных ядерных испытаний близ границ Канады.

С расширением сферы безраздельной компетенции провинций постепенно вышло из употребления федеральное вето. Правда, вопрос, сложилась ли конституционная конвенция, которая воспрепятствует применению вето, если центр вновь найдет в нем необходимость, остается неурегулированным правовой доктриной.

Широкое участие провинций в реализации внутренней и внешней функций канадского государства является весомым легитимным фактором, облегчающим защиту местных интересов: экономических и экологических - в провинциях англоязычной Канады, языково-культурных - в Квебеке. Этот фактор способствует выведению данных интересов на уровень межгосударственных отношений без нарушения положений Конституции, статутного и прецедентного права. Но одновременно данный фактор затрудняет деятельность федерального центра и создает потенциальную опасность существованию единого государства. До последней четверти XX в. механизмы конституционных конвенций и судебных прецедентов безотказно «работали» на провинции. Бесконтрольное расширение провинциальной и совместной сфер компетенции стало наносить ущерб потребностям развития страны - перемещению рабочей силы, капиталов, товаров и услуг, доступу граждан к пенсиям т.д.

Попытки конституционной реформы оставались в течение полувека (1920-е-1970-е гг.) безрезультатными. Препятствиями были: 1)разнородность требований провинций, 2)их прямая заинтересованность в сохранении статус-кво, 3) сложившееся у каждой провинции в порядке конституционной конвенции право вето над конституционно-правовыми нововведениями. Остров Принца Эдуарда с 1\% населения страны пользовался правом блокировать принятие поправок к АБСА на том же основании и в том же порядке, что и Квебек (28\% населения страны) или Онтарио (32\% населения). В правовой литературе данное положение вещей именовалось «конституционным тупиком». Не удавалось согласовать ни общей концепции реформы, ни сроков и методов ее реализации. Открытым оставался вопрос о патриации АБСА - его выведении из юрисдикции метрополии. Сохранение рудиментов колониальной зависимости отвечало интересам провинций в большей мере, чем их устранение ${ }^{15}$. Поэтому обретение Канадой юридического суверенитета происходило низкими темпами. Институт канадского гражданства был учрежден парламентским статутом лишь после Второй Мировой войны - в 1947 г. Национальный флаг доминион обрел в 1965 г. опять-таки на основании статута, не имеющего силы конституционной поправки.

Курс на форсирование конституционной реформы Оттава взяла только с образованием в Квебеке правительства сепаратистов в 1976г. При ее подготовке центр стал использовать издание Белых книг ${ }^{16}$ по конституционным проблемам и телевизионные обращения к провинциальным премьерам (фактически - к общественности). Среди предложений Оттавы по конституционной тематике стали фигурировать:

- толкование федерально-провинциального консенсуса как желательного (но не обязательного) условия проведения реформы;

- замена идеи всеобъемлющей конституционной реформы пересмотром отдельных устаревших статей АБСА;

- согласие на расширение совместной(но не безраздельной провинциальной) сферы компетенции над коммуникациями, прямыми налогами, социальными программами и над торговлей энергоносителями при условии адекватного расширения федеральной компетенции над перемещением капиталов, рабочей силы и товаров и над общим управлением экономикой в ситуациях, затрагивающих общегосударственные интересы;

- предложение о дополнении АБСА Хартией прав и свобод канадцев (ХПСК);

- предложение о конституционном закреплении национального гимна;

- обещание аннулировать федеральное вето над провинциальным статутным правом ${ }^{17}$.

\footnotetext{
${ }^{15}$ Упорная оппозиция провинций ко многим инициативам Оттавы не мешает центру выплачивать им т.н. выравнивающие выплаты, а субъектам - получать их. В сфере федерально-провинциальных отношений тенденции к противоборству и к сотрудничеству развивались и развиваются в Канаде одновременно.

${ }^{16}$ Белые (цветные) книги - публикации о намерениях действий правительства на среднесрочную перспективу. Имеют официальный характер, но не обладают обязывающей силой. Выполняют функцию одного из средств диалога правительства с общественностью.

${ }^{17}$ Характеризуя масштаб обещанных тогда провинциям уступок, премьер-министр П.Трюдо образно говорил: «Вместе с товаром я почти продал и магазин» (P.Trudeau . Memoirs. Toronto, 2000. P.300).
} 
Комплекс основополагающих трудностей федеральной власти заключался во-первых, в том, чтобы сделать уступки тормозом квебекскому сепаратизму, а не подспорьем ему. Во-вторых, при умиротворении быстро развивающихся, но все еще периферийных западных провинций во главе с Альбертой не следовало жертвовать интересами ключевой провинции Онтарио. Уступать одному Квебеку значило играть на руку центробежным силам западных провинций, и наоборот. Уступать же всему провинциальному уровню власти значило толкать страну к распаду.

Большинство субъектов восприняло идею перераспределения сфер компетенции отрицательно. Провинции интересовались исключительно перспективами расширения сферы их безраздельной компетенции. Они предъявляли дополнительные условия: неприкосновенность провинциального вето, полноправное участие субъектов во всех процедурах реформы, в формировании Сената. Провинциями была выдвинута идея создания формируемого исключительно ими Конституционного суда с передачей ему права толкования Конституции. В противовес Оттаве Альберта и Британская Колумбия опубликовали собственные проекты обновления Конституции. Правительство Альберты обратилось в Верховный суд Канады (ВСК) с просьбой проверить предложения центра на совместимость с Конституцией (дело «Альберта против Генерального прокурора Канады»). От необходимости стать ответчиком в суде генпрокурора доминиона избавил роспуск Палаты общин в связи с назначением очередных парламентских выборов ${ }^{18}$. Реформа была еще раз отсрочена.

Политические предпосылки конституционной реформы стали более благоприятными с успехом федералистов на квебекском референдуме 1980г. Активность главного носителя сепаратистской опасности - правительства Квебека, проигравшего референдум, пошла на спад. Федеральный кабинет провозгласил патриацию АБСА неотъемлемой частью реформы и вовлек провинции в цикл конституционных конференций, продолжавшийся около полугода. Подготовительную работу выполнил образованный при ФПК Конституционный комитет, состоявший из министров и заместителей министров юстиции и заседавший попеременно в разных городах. Названные мероприятия были открытыми и впервые транслировались в прямом эфире, что должно

\footnotetext{
${ }^{18}$ Предвыборный роспуск Палаты общин лишил силы все билли, поступившие в Палату в течение сессии и не прошедшие третьего чтения. Соответственно ВСК изъял из графика работы принятую им к рассмотрению жалобу правительства Альберты.
}

было воспрепятствовать саботированию реформы провинциями. Но прийти к консенсусу снова не удалось. Наглядно вскрылась неспособность провинций договориться не только с Оттавой, но и друг с другом.

Единственным достижением цикла конституционных конференций явилось постановление ФПК о раздельных переговорах по коренным - собственно правовым и «сопутствующим» (экономическим) проблемам. Безусловный приоритет конституционно-правовой тематики перед экономическими («хозяйственными») вопросами подтвердил готовность сторон продолжать действовать в рамках верховенства права, невзирая на экономические трудности.

Рассогласованность действий субъектов была расценена центром в качестве устойчивого политического фактора, автоматически снимающего препоны на пути федеральных конституционных инициатив. Исходя из выгодной политической обстановки, федеральные политики объявили в сентябре 1980г., что не считают себя связанными конвенциями, требующими федерально-провинциального согласия, и переходят к односторонней патриации. Таким образом, федеральная исполнительная власть самостоятельно, помимо судебной власти дала новое толкование одному из ключевых положений неконсолидированной Конституции, пусть и не защищенному статутным правом и судебными решениями.

На обсуждение проекта Конституционной резолюции парламенту был выделен 150-дневный срок. Резолюция состояла из трех блоков. Вводный блок содержал просьбу к парламенту Великобритании принять Акт о Канаде. Вторым блоком являлся Акт о Канаде, который придавал законную силу поправкам к АБСА и выводил его из-под юрисдикции метрополии. Третьим блоком резолюции был дополненный и переименованный в Конституционный акт АБСА. В третьем блоке размещалась подготовленная по настоянию и при участии премьер-министра Хартия прав и свобод канадцев.

Обладая большинством в парламенте, правительство добилось одобрения Конституционной резолюции в двух чтениях. Но тем временем восемь провинций, объединившихся вокруг Альберты и Квебека, вернулось к согласованным контрдействиям ${ }^{19}$. Они демонстративно провели отдельную конституционную конференцию, где отвергли ХПСК как вторгающуюся в сферу безраздельной провинциальной компетенции. Условием поддержки конституционной реформы «банда восьми» поставила предварительное

\footnotetext{
${ }^{19}$ На стороне центра остались только Онтарио и Нью-Брансуик.
} 


\section{Право и политика 5 (185) • 2015}

согласие законодательных органов всех субъектов федерации. Совместимость односторонней патриации с Конституцией была ими оспорена в высших судах Квебека, Манитобы и Ньюфаундленда.

В федеральном парламенте официальная оппозиция, применившая тактику обструкции, на несколько недель парализовала деятельность Палаты общин. Третье чтение резолюции стало невозможным. Правительству пришлось пойти на идеологические уступки. Оно согласилось внести в конституционную преамбулу норму-принцип о власти Бога над обществом. Рассмотрение резолюции в третьем чтении было отложено до решения судов о законности односторонней патриации. Вместе с тем требования официальной оппозиции преобразовать ФПК в постоянно действующий институт Палата по настоянию правительства отклонила.

Когда правительство пришло к согласию с парламентской оппозицией, центром противодействия реформе вновь стал провинциальный уровень власти. Судебные процессы о патриации заняли почти год. Апелляционный суд Квебека 4 голосами против одного и Верховный суд Манитобы 7 голосами против двух, толкуя положения позитивного права, нашли, что односторонняя патриация совместима с Конституцией. Апелляционный суд Ньюфаундленда, исходивший из толкования прецедентов и конституционных конвенций, единодушно вынес вердикт противоположного содержания ${ }^{20}$. Опираясь на него, восемь провинциальных генеральных прокуроров немедленно обратились с иском к федеральному правительству в Верховный суд Канады. Правительству пришлось вторично прервать парламентские прения о конституционной реформе и стать ответчиком в новом судебном процессе (дело «Генпрокуроры провинций против Генпрокурора Канады»).

После трехмесячного разбирательства ВСК 6 голосами против 3 вынес решение, которое признало одностороннюю федеральную патриацию совместимой с буквой Конституции и позитивным правом страны, но вместе с тем «нарушающей дух Конституции», т.е. несовместимой с конституционными конвенциями.

\footnotetext{
${ }^{20}$ Действия высших провинциальных судов всецело подтверждают справедливость мнения о независимости судебной власти Канады от исполнительной. Одностороннюю патриацию должны были бы отвергнуть прежде всего судьи Квебека и Манитобы - провинций с правительствами антицентралистской окраски и к тому же мало зависящих от федеральной финансовой помощи. Вместо этого единственной инстанцией, вынесшей решение не в пользу центра, стали судьи Ньюфаундленда - провинции, в наибольшей мере зависящей от федеральных выплат!
}

Концепция реформы сомнению не подвергалась. Но Суд объявил обязательным условием законности методов реформы предварительное соглашение и сотрудничество центра с «существенным большинством» субъектов. Точного критерия существенного большинства верховные судьи не сформулировали. Провинциям Верховный суд напомнил об их обязанности, а не праве участвовать в процедурах патриации ${ }^{21}$.

В сущности позиция, которую занял ВСК в регулировании конституционного конфликта, была компромиссной. Напомнив федеральной исполнительной власти о месте и роли конвенций в конституционном праве страны, верховные судьи одновременно высказались против очередной (уже седьмой по счету) попытки провинциального уровня власти воспрепятствовать конституционной реформе ${ }^{22}$.

Несмотря на внутреннюю противоречивость решения ВСК, на известную растяжимость его формулировок и на разделение мнений судей, федеральный кабинет констатировал провал курса на одностороннюю патриацию. Квалифицировав вердикт Верховного суда как «политизированный» ${ }^{23}$, правительство тем не менее подчинилось ему. Более того, центру удалось превратить неугодное ему решение Суда в дополнительный императив конституционной реформы. Премьер-министр призвал провинциальных премьеров «использовать последний шанс» -сообразно с вердиктом Верховного суда и совместно с центром патриировать АБСА. Министерство юстиции и Секретариат премьер-министра проработали несколько сценариев возможных действий. Общим компонентом всех вариантов было терпеливое отсечение экстремистских требований Квебека и Альберты. Было упрочено взаимодействие с органами исполнительной власти Онтарио и Нью-Брансуика и получено согласие правительства Саскачевана выполнить функцию посредника между центром и лидерами провинциальной оппозиции.

Блокируясь с тремя провинциями, центр предложил провести совместную патриацию АБСА без вызывавших самые глубокие разногласия положений

\footnotetext{
${ }^{21}$ Swinton K. The Supreme Court and the Constitution. Toronto, 1996. P. 35 .

22 Провинции впервые воспрепятствовали конституционной реформе в 1927 г. (инициатор - Онтарио), во второй раз - в 1935 г. (инициаторы - большинство провинций), в третий раз - в 1950 г. (инициатор -Квебек), в четвертый, пятый и шестой раз - в 1961, 1965 и 1971 гг. (инициатор - Квебек).

${ }^{23}$ «Верховному суду лучше было не вмешиваться в политические дела», - с досадой говорил много лет спустя, находясь уже в отставке, П.Трюдо (Rethinking the Constitution / ed.by Peacock A. Oxford, 1999. P.202)
} 
- о Хартии прав и свобод и о процедуре конституционных поправок, но с оговоркой, что через два года они будут вынесены на общенациональный референдум в двух вариантах - федеральном и провинциальном. Охотное одобрение предложения правительством Квебека позволило центру внести раскол в оппозицию. Предложение обновлять Конституцию при помощи института прямой демократии шло вразрез с верховенством парламента и не могло получить поддержки в англоязычных субъектах федерации. Многие лидеры оппозиции стали к этому времени тяготиться совместными действиями с непопулярным в англоязычной Канаде Квебеком. В ноябре 1981г. «банда восьми» распалась: англоязычные провинциальные премьеры подписали с премьер-министром Соглашение о совместной патриации Конституции. Оно закрепило комплекс обоюдных уступок двух уровней власти:

- передачу на последующее решение судами и/или федерально-провинциальных конференций ряда спорных вопросов - о применении норм ХПСК, о формировании Сената, о компетенции над континентальным шельфом и брачно-семейным законодательством;

- отказ субъектов от возражений против внесения ХПСК в Конституцию;

- снятие субъектами требований о финансовой компенсации при их неучастии в соглашениях с центром;

- снятие субъектами возражений против применения законодательства о двуязычии в сфере федеральной компетенции;

- отказ центра от институционализации конституционных референдумов.

Соглашение о патриации не стало общенациональным: его не подписал Квебек. Его правительство, назвавшее день заключения Соглашения «днем гнева и позора», отказалось от участия в дальнейших процедурах реформы и снова оспорило ее законность в судах всех инстанций. Но на этот раз Апелляционный суд провинции, Верховный суд Канады и Судебный комитет Тайного совета в Лондоне в решениях по жалобам правительства Квебека подтвердили, что патриация АБСА, реализованная центром совместно с «существенным большинством провинций», не противоречит букве и духу Конституции. Коллизионный этап реформы остались позади.

Успех федерального центра объяснялся его лояльным следованием решению ВСК, отказом от прямолинейных методов односторонней патриации Конституции, блокированием с правительствами Онтарио, Нью-Брансуика и Саскачевана, а также умелым использованием антиквебекских настроений англоязычной общественности и англоязычных провинциальных правительств.

Когда Конституционная резолюция была поставлена на голосование в парламенте в третьем чтении, степень консенсуса оказалась значительно выше среднестатистической, а обычно высокая доля отсутствующих депутатов - низкой. Резолюцию отказалась поддержать лишь небольшая часть депутатов-заднескамеечников. Она была одобрена 246 голосами против 24. Из 75 депутатов от Квебека против конституционной реформы проголосовало всего два. Отсутствие согласия правительства Квебека с резолюцией не было сочтено «отсутствием мандата квебекского народа». Подписанная генерал-губернатором Канады, резолюция была затем утверждена Палатой общин парламента Великобритании 177 голосами против 33. Это было последнее голосование парламента Соединенного Королевства по вопросам Конституции Канады.

Реформа, называемая в литературе «конституционной одиссеей», заняла в общей сложности пять лет. Церемония передачи обновленной Конституции в безраздельную юрисдикцию Канады состоялась 17-18 апреля 1982 г. в центре Оттавы в присутствии почти 30 тыс. зрителей. С этого дня Конституция страны носит наименование Конституционного акта, в котором амальгамирован Акт 1867г. и часть современных поправок к нему. Акт о Британской Северной Америке стал достоянием истории.

Значение конституционной реформы состоит в следующем:

1. Канада преодолела почти 60-летний «конституционный тупик», что позволило ей вслед за политическим суверенитетом обрести суверенные права в конституционно-правовой сфере. Осуществив реформу, канадцы устранили еще один весомый пережиток былого колониального статуса, что нашло адекватное отражение в конституционно-правовой и международно-правовой сфере. Страна не только фактически, но и юридически перестала считаться доминионом, а Соединенное Королевство - ее метрополией. Эти термины, более не применимые к конституционному строю Канады, вышли из употребления. В правовой доктрине и практике перестал также использоваться юридически безграмотный в применении к Канаде термин «конфедерация».

2. Неконсолидированная Конституция обновлена на базе правовых и экономических реалий современности. Прекращено действие не менее чем 20 наиболее архаических статей Акта 1867г. Перераспределены сферы ответственности двух уровней власти. Сфера 
DOI: $10.7256 / 1811-9018.2015 .5 .13829$

При цитировании этой статьи сноска на dоі обязательна

\section{Право и политика 5 (185) 2015}

провинциальной компетенции расширена в социальной и культурной областях, тогда как сфера федеральной компетенции - в сфере экономики. Закреплен современный механизм и новые процедуры принятия конституционных поправок.

3. Права граждан страны упрочены, расширены и кодифицированы путем внесения в Конституционный акт Хартии прав и свобод канадцев, положения которой имеют одинаковую юридическую силу на всех уровнях публичной власти. Нормы ХПСК подлежат толкованию исключительно органами судебной власти, что, по оценкам правоведов, облегчает и укрепляет защиту прав и свобод личности. Хартия, получившая неформальное наименование «народного пакета», в кратчайший срок стала самой известной и наиболее популярной частью реформированной Конституции и сохраняет это положение до сих пор.

4. В Конституционном акте присутствует новаторское и гибкое положение о праве каждого из правительств - провинциального или федерального на периодическую (раз в пятилетие) постановку вопроса о пересмотре вызывающих его возражения норм ХПСК. Этот вопрос входит в сферу компетенции федеральнопровинциальных конференций.

5. Принципам двуязычия (равного статуса английского и французского языков в сфере федеральной компетенции), имеющим важное значение для развития национального самосознания канадцев, придана сила конституционной гарантии.

Многообразные коллизии, возникшие в ходе реализации конституционной реформы, имели как правовое, так и политическое содержание при очевидном примате права. Правомерность основных действий федеральной исполнительной власти была подтверждена органами провинциальной и федеральной судебной власти. Отказ судов двух уровней признать методы патриации совместимыми с духом Конституции не привел ни к затяжному конфликту исполнительной и судебной власти, ни к срыву реформы, на что рассчитывала часть провинциальных лидеров. Вместо этого со стороны федеральной испол- нительной и законодательной власти последовали новые конструктивные и юридически безупречные инициативы. Уважение к судебной власти, бережное отношение к основам сложившейся в стране самобытной модели федерализма принесли центру заслуженный успех.

Деятели федеральной власти, устранив стоявшие перед ними препятствия в рамках верховенства права, продемонстрировали высокий уровень искусства государственного управления, достойный конституционного демократического государства.

К числу недостатков конституционной реформы принадлежит ее незавершенность в пространстве. К реформе не присоединился Квебек. В день передачи Канаде юрисдикции над Конституцией его Национальное собрание объявило перерыв в сессии, флаги провинции повсеместно были приспущены, общественность провела демонстрации протеста. Несмотря на смены правящей партии провинции в 1994, 2003, 2011 и 2014 гг., Национальное собрание и правительство Квебека продолжают не признавать законной силы ряда норм ХПСК и всего Конституционного акта в целом, хотя и не отказываются подчиняться ему (кроме ХПСК) ${ }^{24}$.

Позиция, занимаемая институтами власти Квебека в конституционном вопросе, не является уникальной. Она сходна с аналогичной позицией институтов власти Баварии в ФРГ ${ }^{25}$. В конституционном развитии других федеративных государств подобных прецедентов нет.

Реформа не означала ломки конституционного строя Канады. Конституция страны по-прежнему не консолидирована, и главой суверенного государства номинально остается британский монарх (монархиня), уполномоченным которого считается генерал-губернатор. По-прежнему является назначаемым органом Сенат Канады, построенный во многом по образцу британской Палаты лордов. Целый ряд статутов, судебных прецедентов и конституционных конвенций Соединенного Королевства сохраняет исторически сложившееся значение действующих источников конституционного, гражданского и уголовного права современной Канады.

\section{Библиография:}

1. Богдановская И.Ю. Прецедентное право. - М.: Наука, 1993.

2. Богдановская И.Ю. Классификация конституций стран «общего права» // Право. Журнал Высшей школы экономики. 2012. №1.

\footnotetext{
${ }^{24}$ Подробнее см.: Данилов С.Ю. Правовое регулирование специального статуса субъекта федерацииб дифференциация права на примере статуса Квебека // Право. Журнал Высшей школы экономики. 2012. №2. С.99- 108 .

${ }^{25}$ См.: Белов В.Б. Бавария в системе германского федерализма. M.. 2003
} 
DOI: $10.7256 / 1811-9018.2015 .5 .13829$

При цитировании этой статьи сноска на dоі обязательна

Трансформация правовых и политических систем

3. Богдановская И.Ю. Эволюция судебного прецедента в «общем праве // Право. Журнал Высшей школы экономики. 2010. №2

4. Данилов С.Ю. История Канады. - М.: Весь мир, 2006.

5. Данилов С.Ю. Эволюция канадского федерализма. - М.: Издательский дом НИУ ВШЭ, 2012.

6. Данилов С.Ю. Правовое регулирование «специального статуса» субъекта федерации: дифференциация права на примере Квебека // Право. Журнал Высшей школы экономики. 2012. №2.

7. Еллинек Г. Общее учение о государстве. СПБ.: Юридический пресс-центр, 2005.

8. Качанов В.А. Федерализм в Канаде / Современный буржуазный федерализм. М.: Наука, 1978.

9. Сравнительное конституционное право / Под ред. Чиркина В.Е. и др. - М.: Международные отношения, 2001.

10. Boyer P. Direct Democracy in Canada. Toronto, 1992. Canada. A Consolidation of Constitutional Acts. 1867 - 1982. Ottawa, 2001.

11. The Crosscurrents. Centralization vs. Separatism / ed. Charlton M., Barker P. Scarborough (Ont. ), 1994.

12. Hogg P. The Constitutional Law of Canada. Agincourt (Ont.), 2007.

13. Jovell J. et al. The Changing Constitution. Oxford, 2000. McWhinney E. Canada and the Constitution. Toronto, 1992.

14. Reid S. The Breakup of Quebec. Democracy and Dangers of Partition. Peterborough (Ont.), 2006.

15. Russell P. The Constitutional Odyssey. Toronto, 1992. Rethinking the Constitution. Perspectives on Canadian Constitutional

16. Reform, Interpretation and Theory / ed. Peacock A. Oxford - New York, 1996.

17. Trudeau P. Memoirs. Toronto, 2000.

\section{References (transliterated):}

1. Bogdanovskaya I.Yu. Pretsedentnoe pravo. - M.: Nauka, 1993.

2. Bogdanovskaya I.Yu. Klassifikatsiya konstitutsii stran «obshchego prava» // Pravo. Zhurnal Vysshei shkoly ekonomiki. 2012 . №1.

3. Bogdanovskaya I.Yu. Evolyutsiya sudebnogo pretsedenta v «obshchem prave // Pravo. Zhurnal Vysshei shkoly ekonomiki. 2010 . №2.

4. Danilov S.Yu. Istoriya Kanady. - M.: Ves' mir, 2006.

5. Danilov S.Yu. Evolyutsiya kanadskogo federalizma. - M.: Izdatel'skii dom NIU VShE, 2012.

6. Danilov S.Yu. Pravovoe regulirovanie «spetsial'nogo statusa» sub"ekta federatsii: differentsiatsiya prava na primere Kvebeka // Pravo. Zhurnal Vysshei shkoly ekonomiki. 2012. №2.

7. Ellinek G. Obshchee uchenie o gosudarstve. SPB.: Yuridicheskii press-tsentr, 2005.

8. Kachanov V.A. Federalizm v Kanade / Sovremennyi burzhuaznyi federalizm. M.: Nauka, 1978.

9. Boyer P. Direct Democracy in Canada. Toronto, 1992. Canada. A Consolidation of Constitutional Acts. 1867 - 1982. Ottawa, 2001.

10. Hogg P. The Constitutional Law of Canada. Agincourt (Ont.), 2007.

11. Jovell J. et al. The Changing Constitution. Oxford, 2000. McWhinney E. Canada and the Constitution. Toronto, 1992.

12. Reid S. The Breakup of Quebec. Democracy and Dangers of Partition. Peterborough (Ont.), 2006.

13. Russell P. The Constitutional Odyssey. Toronto, 1992. Rethinking the Constitution. Perspectives on Canadian Constitutional

14. Reform, Interpretation and Theory / ed. Peacock A. Oxford - New York, 1996.

15. Trudeau P. Memoirs. Toronto, 2000. 